\title{
ELECTRICITY STORAGE IN ENERGY CLUSTERS
}

\author{
Grzegorz Kunikowski, PhD Eng. \\ Faculty of Management, Warsaw University of Technology
}

\begin{abstract}
The article aims to present the results of analysis and evaluation of using energy clusters as a bulk electricity storage. There were developed an analytical model of a sample microgrid (on-grid) and analysed using a software dedicated for optimizing such microgrids. The model of microgrid consist on electricity commercial and residential loads, photovoltaic and wind installations and batteries.
\end{abstract}

Keywords: energy clusters, electricity storage, microgrid

\section{INTRODUCTION}

Energy clusters are a sample of implementation a concept of distributed renewable energy installations integrated with existing technical infrastructure.

The legal basis for energy clusters development in Poland is the Act on renewable energy resource, [1]. Energy-related clusters are associated with technological trends, as generation of energy in renewable sources (RES), electricity storage, and are significantly supported by favorable legal solutions and financial support.

Regardless of the indicated advantages of clusters, the main barrier to the widespread development of distributed energy is high capital expenditure (CAPEX), access to energy grids and maintaining continuity of electricity supply. The cost of electricity generated in RES installations is higher than the cost of energy generated in a centralized system, the National Power System (NPS), based on stable conventional sources, which benefit from economy of scale and relatively low prices of coal. Energy clusters are expected to contribute to reducing energy production costs in an alternative way to NPS. One of the basic arguments used as justification for the functioning of clusters are the benefits of balancing. This effect can be achieved by using their basic advantages (clusters), which is the ability to produce energy in the local area in a manner coordinated with the current demand [2].

The most commercially mature solutions in the local production of electricity are wind farms and photovoltaic installations, while as prospective solutions are considered fuel cells. For weather-dependent unstable solutions, the ability to store energy, for instance during a day, is crucial, which is necessary in case of balancing the needs of individual recipients. The use of solar energy is also considered in the propulsion of light aircraft applications, and this problem, taken before years in the theoretical perspective 
[3,4], found implementation in pioneer solutions [5].Currently there are deployed following types of technological solutions for electricity storage: electro-chemical, electro-mechanical, chemical, pumped hydro storage and thermal storage [6]. Pumped hydro storage is the largest single source of electrical storage capacity in the world, with $169 \mathrm{GW}$ of power operational capacity [6,7].

Besides storage, the ability for balancing demand and supply of electricity in microgrid may be socalled bulk storage. [8] indicates that the best energy mix in the microgrids is $80-89 \%$ from microgrid and $11-20 \%$ from the main grid. In turn, a sample microgrid project in California was supposed to prove that integration of distributed sources and storages can reduce demand up to $15 \%[9]^{1}$.

The aim of the article is to conduct a quantitative analysis of the efficiency of electricity supply balancing, produced in distributed RES installations with demand, described using electricity loads for individual and commercial categories of final consumers.

As a result, we attempt to answer questions about the efficiency of the microgrids with distributed RES installations in electricity storage by balancing loads and supply and the use of batteries.

\section{METHODOLOGY}

In order to analyze the balancing of electricity demand and supply, we propose using a dedicated tool for simulating a cluster during a given period of time and working conditions. The tool we use, HOMER is a software for microgrid and distributed generation power system design and optimization. Homer software is widely used in similar analysis regarding integrating RES instalations in microgrids [10-12]. We use it for modeling defined a cluster, which in the program operates as a microgrid, later called 'the model' in the text (Fig. 1).

The purpose is to answer previously raised issues. In order to find the answer, we use a sensitivity analysis so-called 'what if' to get the more precise view on interdependent characteristics.

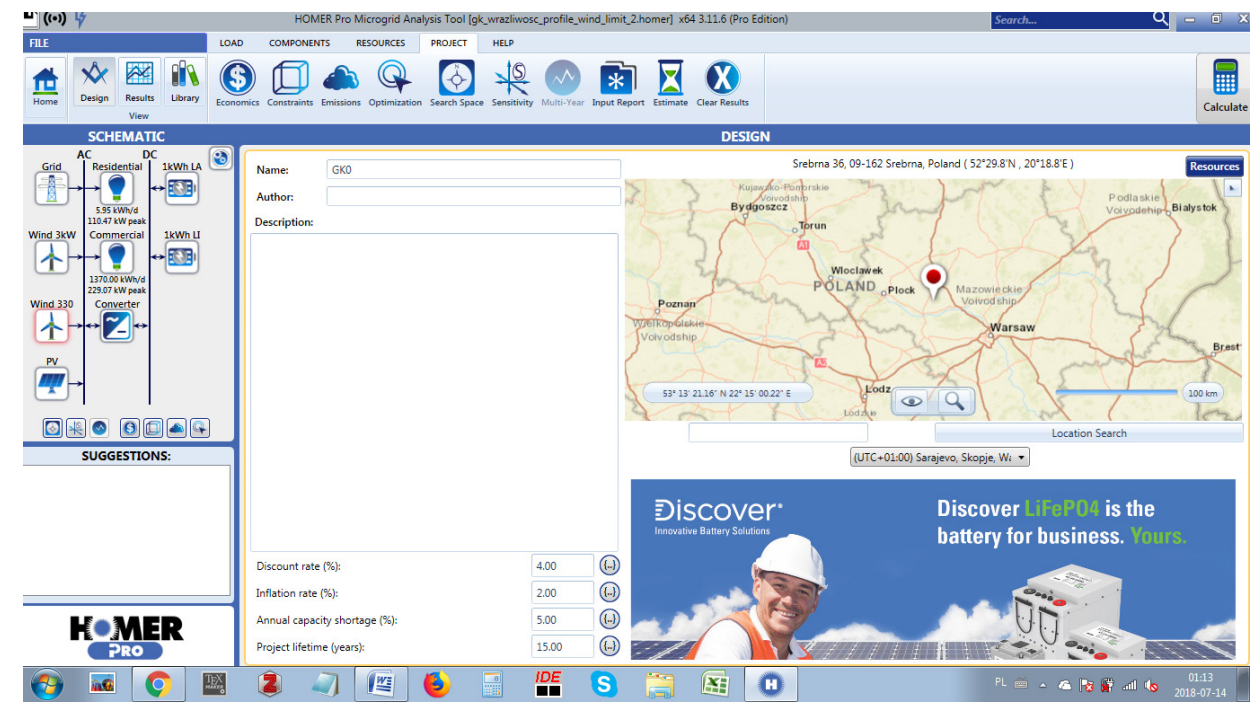

Fig. 1 The model of cluster used for simulations and sensitivity analysis

${ }^{1}$ More sample microgrid projects can be found at: https://building-microgrid.lbl.gov/examples-microgrids (2018.06.14) 
The HOMER program for the defined model performs simulations, taking into account weather conditions (in this case solar radiation and wind speed) and techno-economical characteristics of predefined installations (Tab. 1) analyzed in indicated search space (Tab. 2). Then HOMER generates the most favorable solutions in terms of the criteria and boundary conditions indicated.

Tab. 1. Main techno-economical assumptions used in the model ${ }^{2}$

\begin{tabular}{|c|c|c|c|c|}
\hline \multicolumn{2}{|c|}{ Component } & \multirow{2}{*}{$\begin{array}{c}\text { Values } \\
0,55\end{array}$} & \multirow{2}{*}{$\begin{array}{c}\text { Units } \\
\text { PLN/kWh }\end{array}$} & \multirow{2}{*}{$\begin{array}{c}\text { Note } \\
\text { Including all costs and fees }\end{array}$} \\
\hline Grid & Power price & & & \\
\hline Grid & Sellback price ${ }^{3}$ & 0,40 & PLN/kWh & \\
\hline \multirow[t]{2}{*}{ Demand loads } & Residential & 5,95 & kWh/day & $\begin{array}{c}\text { Based on statistical } \\
\text { annual consumption }^{4}\end{array}$ \\
\hline & Commercial & 1.370 & $\mathrm{kWh} /$ day & \\
\hline \multirow{2}{*}{ Wind turbines } & $3 \mathrm{~kW}$ & 25.000 & PLN & CAPEX \\
\hline & $330 \mathrm{~kW}$ & 1.500 .00 & PLN & CAPEX \\
\hline \multirow{2}{*}{ PV } & Panel & 5.000 & $\mathrm{PLN} / \mathrm{kW}$ & CAPEX \\
\hline & Converter & 300 & $\mathrm{PLN} / \mathrm{kW}$ & CAPEX \\
\hline \multirow{2}{*}{ Storage } & Lead-Acid $1 \mathrm{kWh}$ & 1.000 & PLN & CAPEX \\
\hline & Li-Ion $1 \mathrm{kWh}$ & 1.300 & PLN & CAPEX \\
\hline
\end{tabular}

Tab. 2. Search space for the model of cluster

\begin{tabular}{|c|c|c|c|c|c|}
\hline \multirow{2}{*}{ PV Size, kW } & \multirow{2}{*}{$\begin{array}{c}\text { Converter } \\
\text { capacity, kW }\end{array}$} & \multicolumn{2}{|c|}{ Battery strings, number } & \multicolumn{2}{c|}{ Wind, number } \\
\cline { 3 - 6 } & Lead-Acid $\mathbf{1} \mathbf{k W h}$ & Li-Ion $\mathbf{1} \mathbf{k W h}$ & $\mathbf{3} \mathbf{~ k W}$ & $\mathbf{3 3 0} \mathbf{~ k W}$ \\
\hline 0 & 0 & 0 & 0 & 0 & 0 \\
\hline 50 & 1 & 1 & 1 & 1 & 1 \\
\hline 100 & 10 & 10 & 10 & 2 & 2 \\
\hline 250 & 50 & 100 & 50 & & 5 \\
\hline & 100 & & & & \\
\hline
\end{tabular}

Presented data (Tab. 1) were a part of complete set of detailed assumptions, all important, but not key once from the perspective of the aim of the article. These data include general financial assumptions, for instance expected inflation rate, discount rate; technical constraints, for instance, project lifetime, lifetime of respective components as well.

\footnotetext{
${ }^{2}$ For a larger number of installations, a lower unit price was given.

${ }^{3}$ Net purchases calculated monthly.

${ }^{4}$ Based on statistical data [13].
} 


\section{A}
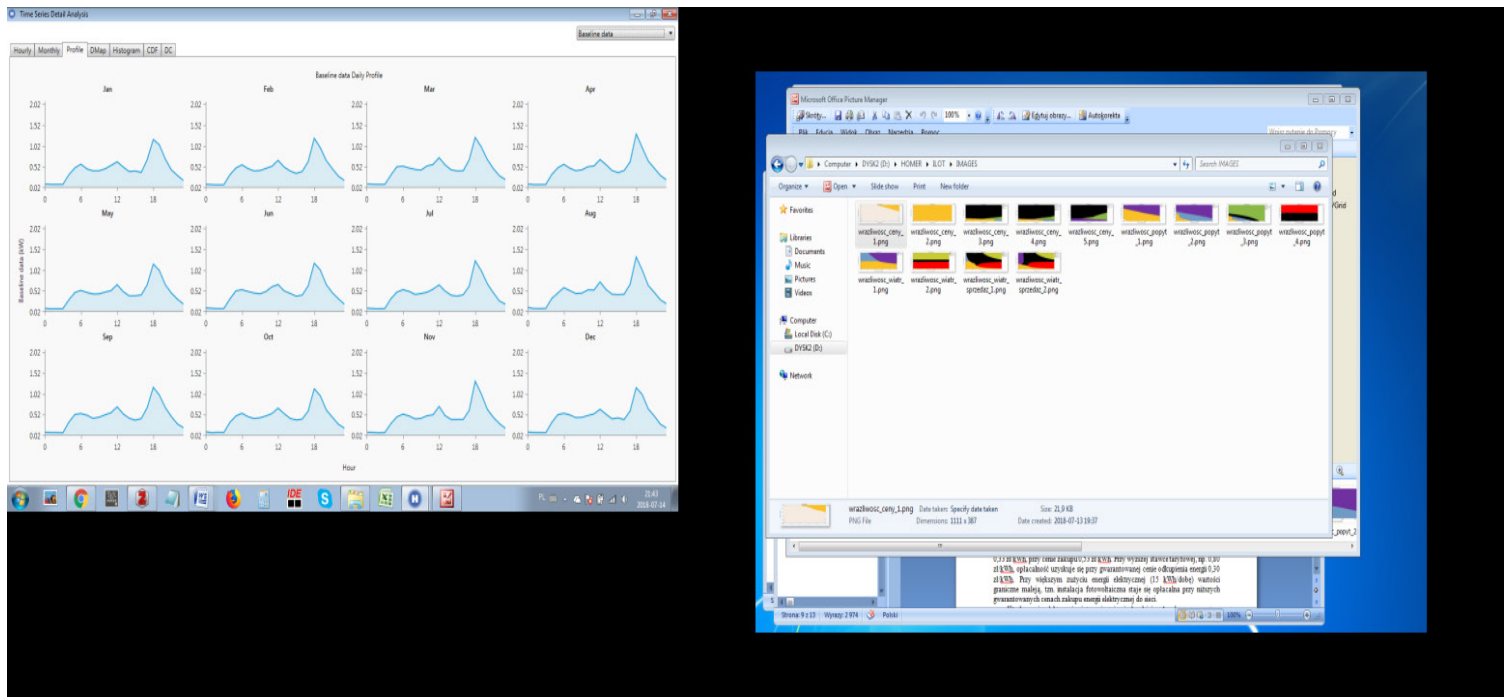

$\mathrm{B}$

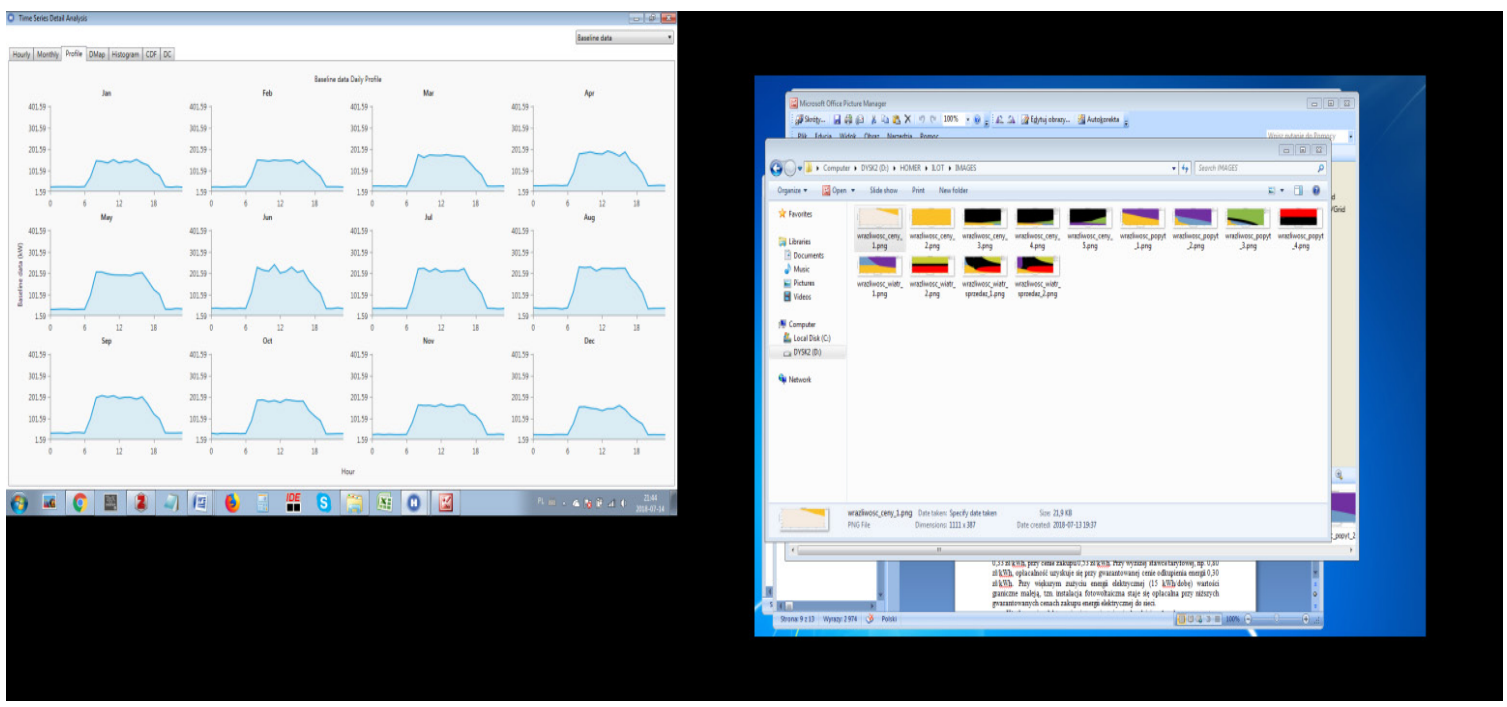

Fig. 2 Electricity consumption baseline data daily profiles: A - residential loads (av. 5,95 kWh/day); B - commercial loads (av. 1.370,00 kWh/day)

The key data selected for the sensitivity analysis as representative and important for the purpose of the research are below (Tab. 3).

The scope of sensitivity analysis had to be limited due to interpretation. The functionality of the program allowed to generate results in two-dimensional graphs (Fig. 3 - Fig. 13), convenient for understanding and discussable interdependence. 
Tab. 3. Values of sensitivity variables

\begin{tabular}{|c|c|c|c|}
\hline \multicolumn{2}{|c|}{ Component } & Values & Units \\
\hline \multirow[b]{2}{*}{ Grid } & Power price & $\begin{array}{l}0,55 \\
0,70\end{array}$ & PLN/kWh \\
\hline & Sellback price & $\begin{array}{l}0,00 \\
0,10 \\
0,40\end{array}$ & PLN/kWh \\
\hline \multirow{2}{*}{ Demand loads } & Residential & $\begin{array}{c}5,95 \\
59,50 \\
595,00 \\
\end{array}$ & $\mathrm{kWh} /$ day \\
\hline & Commercial & $\begin{array}{c}0 \\
685 \\
1.370\end{array}$ & $\mathrm{kWh} /$ day \\
\hline Wind speed & NASA data & $\begin{array}{l}3,00 \\
4,79 \\
7,00\end{array}$ & $\mathrm{~m} / \mathrm{s}$ \\
\hline
\end{tabular}

\section{RESULTS}

The presented below simulation results indicate the energy cost (PLN / kWh) achievable for optimal generic microgrid the program has configured. The reference value in all sensitivity analysis case is the price of energy purchased from the power grid. The designated configurations are to be not higher than the reference price, which is the limit value. The results are summarized in tables (Tab. 4).

Tab. 4. The list of results for sensitivity analysis for Power and Sellback prices

\begin{tabular}{|c|c|c|c|c|c|c|c|}
\hline \multirow{2}{*}{ No } & \multirow{2}{*}{$\begin{array}{l}\mathbf{x} \text {-axis } \\
\text { Power } \\
\text { price }\end{array}$} & \multirow{2}{*}{$\begin{array}{l}\text { y-axis } \\
\text { Sellback } \\
\text { price }\end{array}$} & \multicolumn{2}{|c|}{$\begin{array}{c}\text { Electricity loads, } \\
\text { kWh }\end{array}$} & \multirow{2}{*}{$\begin{array}{l}\text { Wind } \\
\text { speed, } \\
\mathrm{m} / \mathrm{s}\end{array}$} & \multirow{2}{*}{$\begin{array}{l}\text { Cost of } \\
\text { energy, } \\
\text { PLN/kWh }\end{array}$} & \multirow{2}{*}{ Components } \\
\hline & & & $\begin{array}{c}\text { Resi- } \\
\text { dential }\end{array}$ & $\begin{array}{c}\text { Com- } \\
\text { mercial }\end{array}$ & & & \\
\hline Fig. 3 & \multirow{5}{*}{$\begin{array}{c}0,55 \\
-0,70\end{array}$} & \multirow{5}{*}{$\begin{array}{c}0,00 \\
-0,40\end{array}$} & 5,95 & 0 & 3 & $0,55-0,70$ & $\begin{array}{l}\text { - GRID } \\
\text { - PV/GRID }\end{array}$ \\
\hline $\begin{array}{l}\text { Fig } 3 \\
\text { Fig. } 4\end{array}$ & & & 5,95 & 685 & 3 & $0,26-0,62$ & - PV/GRID \\
\hline Fig. 5 & & & 5,95 & 685 & 4,79 & $\begin{array}{l}(-0,19)^{5} \\
-0,62\end{array}$ & $\begin{array}{l}\text { - PV/GRID } \\
\text { - PV/Wind3/GRID } \\
\text { - Wind330/1kWhLA/GRID } \\
\text { - Wind 330/GRID }\end{array}$ \\
\hline Fig. 6 & & & 59,5 & 685 & 4,79 & $\begin{array}{l}(-0,19) \\
-0,62\end{array}$ & $\begin{array}{l}\text { - PV/GRID } \\
\text { - PV/Wind3/GRID } \\
\text { - Wind330/1kWhLA/GRID } \\
\text { - Wind330/1kWhLI/GRID } \\
\text { - Wind 330/GRID }\end{array}$ \\
\hline Fig. 7 & & & 595 & 685 & 4,79 & $\begin{array}{l}(-0,16) \\
-0,30\end{array}$ & $\begin{array}{l}\text { - Wind330/1kWhLA/GRID } \\
\text { - Wind330/1kWhLI/GRID } \\
\text { - Wind 330/GRID }\end{array}$ \\
\hline
\end{tabular}

\footnotetext{
${ }^{5}$ Values in brackets means that negative costs of electricity are in fact incomes for the modeled cluster.
} 
Tab. 5. The list of results for sensitivity analysis for Residential and Commercial electricity loads

\begin{tabular}{|c|c|c|c|c|c|c|c|}
\hline No & $\begin{array}{c}\text { x-axis } \\
\text { Residential, } \\
\text { kWh/day }\end{array}$ & $\begin{array}{l}\text { y- axis } \\
\text { Commer- } \\
\text { cial, } \\
\mathrm{kWh} / \text { day }\end{array}$ & $\begin{array}{c}\text { Power } \\
\text { price, } \\
\text { PLN/kWh }\end{array}$ & $\begin{array}{c}\text { Sellback } \\
\text { price, } \\
\text { PLN/kWh }\end{array}$ & $\begin{array}{l}\text { Wind } \\
\text { speed, } \\
\mathrm{m} / \mathrm{s}\end{array}$ & $\begin{array}{c}\text { Cost of } \\
\text { energy, } \\
\text { PLN/kWh }\end{array}$ & Components \\
\hline Fig. 8 & \multirow{4}{*}{$5,95-595$} & \multirow{4}{*}{$\begin{array}{c}0,00 \\
-1.370,00\end{array}$} & 0,55 & 0,00 & 4,79 & $0,28-0,55$ & $\begin{array}{l}\text { - GRID } \\
\text { - PV/GRID } \\
\text { - Wind330/1kWhLI/ } \\
\text { GRID }\end{array}$ \\
\hline Fig. 9 & & & 0,70 & 0,00 & 4,79 & $0,30-0,70$ & $\begin{array}{l}\text { - GRID } \\
\text { - PV/GRID } \\
\text { - PV/Wind3/GRID } \\
\text { - Wind330/1kWhLI/ } \\
\text { - GRID } \\
\text { - Wind330/GRID }\end{array}$ \\
\hline Fig. 10 & & & 0,70 & 0,10 & 4,79 & $0,17-0,70$ & $\begin{array}{l}\text { - GRID } \\
\text { - PV/GRID } \\
\text { - PV/Wind3/GRID } \\
\text { - Wind330/1kWhLA/ } \\
\text { GRID } \\
\text { - Wind 330/GRID }\end{array}$ \\
\hline Fig. 11 & & & 0,70 & 0,40 & 4,79 & $\begin{array}{c}(-0,19)- \\
(-0,11)\end{array}$ & $\begin{array}{l}\text { - PV/Wind330/GRID } \\
\text { - Wind 330/GRID }\end{array}$ \\
\hline
\end{tabular}

Tab. 6. The list of results for sensitivity analysis for Wind speed and Sellback price

\begin{tabular}{|c|c|c|c|c|c|c|c|}
\hline \multirow{2}{*}{ No } & \multirow{2}{*}{$\begin{array}{c}\mathbf{x} \text {-axis } \\
\text { Sellback } \\
\text { price }\end{array}$} & \multirow{2}{*}{$\begin{array}{c}\text { y-axis } \\
\text { Wind } \\
\text { speed, } \mathrm{m} / \mathrm{s}\end{array}$} & \multirow{2}{*}{$\begin{array}{l}\text { Power } \\
\text { price, } \\
\text { PLN/ } \\
\text { kWh }\end{array}$} & \multicolumn{2}{|c|}{$\begin{array}{l}\text { Electricity loads, } \\
\text { kWh/day }\end{array}$} & \multirow{2}{*}{$\begin{array}{c}\text { Cost of } \\
\text { energy, } \\
\text { PLN/kWh }\end{array}$} & \multirow{2}{*}{ Components } \\
\hline & & & & $\begin{array}{l}\text { Residen- } \\
\text { tial }\end{array}$ & $\begin{array}{l}\text { Com- } \\
\text { mercial }\end{array}$ & & \\
\hline Fig. 12 & \multirow{2}{*}{$0,0-0,4$} & \multirow{2}{*}{$3,00-7,00$} & 0,70 & 5,95 & 685 & $\begin{array}{l}(-0,29)- \\
0,55\end{array}$ & $\begin{array}{l}\text { - PV/GRID } \\
\text { - PV/Wind330/Grid } \\
\text { - PV/Wind3/Grid } \\
\text { - Wind330/Grid } \\
\text { - Wind3/Wind330/Grid }\end{array}$ \\
\hline Fig. 13 & & & 0,70 & 595 & 685 & $\begin{array}{c}(-28)- \\
0,54\end{array}$ & $\begin{array}{l}\text { - PV/GRID } \\
\text { - PV/Wind330/Grid } \\
\text { - Wind330/1kWhLI/Grid } \\
\text { - Wind330/Grid } \\
\text { - Wind3/Wind330/Grid }\end{array}$ \\
\hline
\end{tabular}

In the reference conditions, when an average wind speed is $3 \mathrm{~m} / \mathrm{s}$, at a price of $0.55 \mathrm{PLN} / \mathrm{kWh}$ for individual customers (the variant of the lack of demand from commercial entities), the most advantageous solution is to stay with the purchase of energy from the grid. In the case of two conditions combined, an increase in the price of energy and a purchase price of over PLN $0.25 / \mathrm{kWh}$, the preferred option is PV (Fig. 3). 


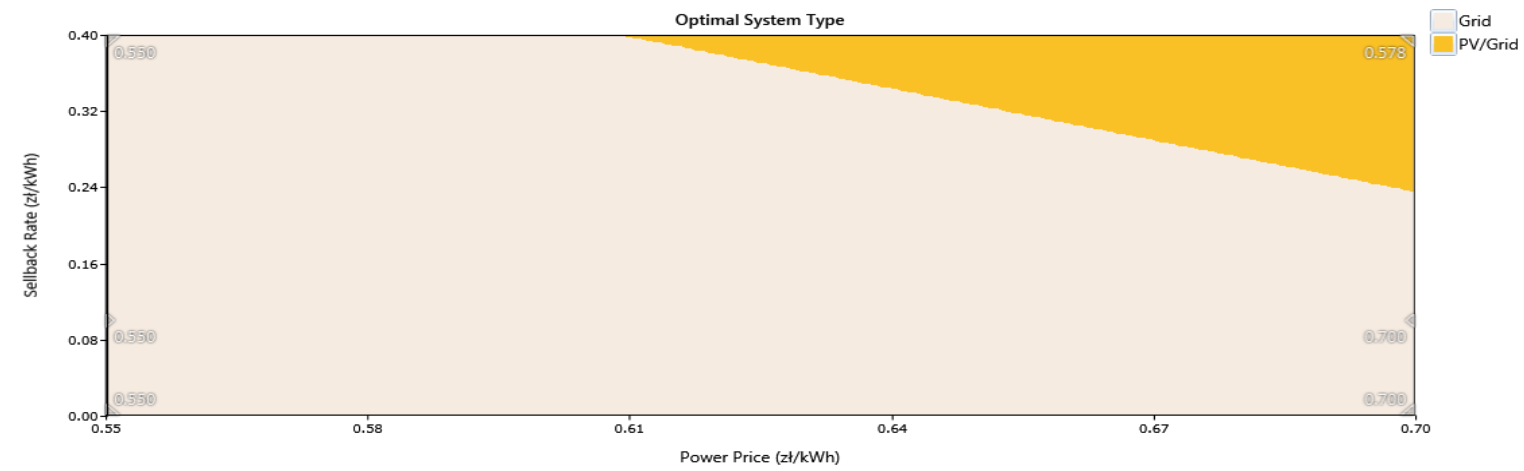

Fig. 3 Sensitivity analysis for Power and Sellback prices. Average wind speed $3 \mathrm{~m} / \mathrm{s}$; Residential load 5,95 kWh/day; Commercial load $0 \mathrm{kWh} /$ day

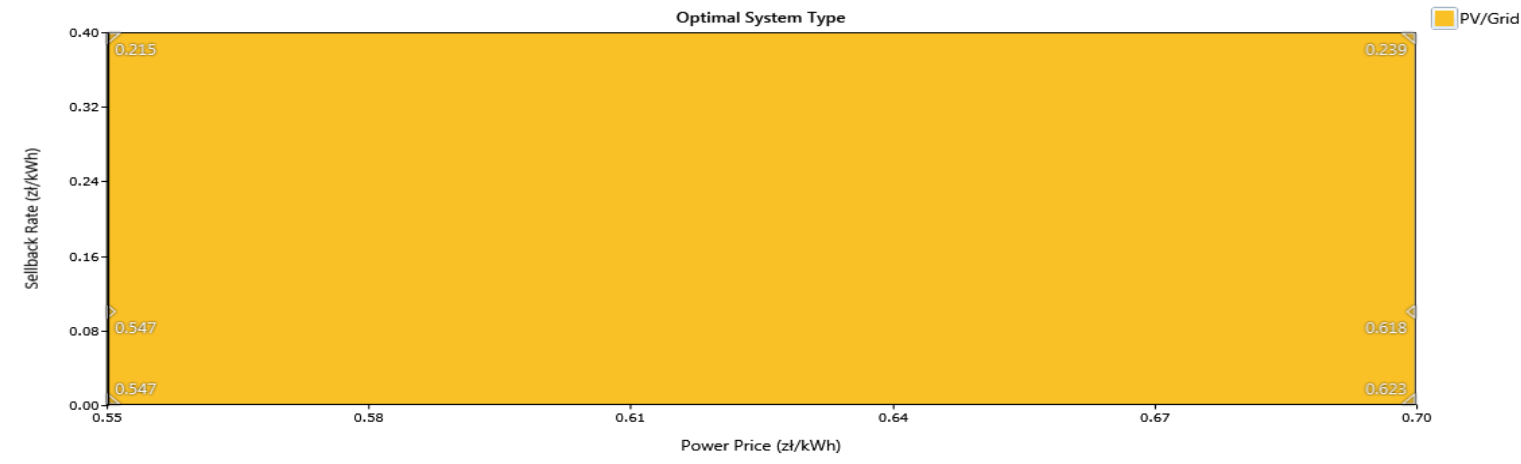

Fig. 4 Sensitivity analysis for Power and Sellback prices. Average Wind speed $3 \mathrm{~m} / \mathrm{s}$; Residential load 5,95 kWh/day; Commercial load $685 \mathrm{kWh}$ /day

With similar conditions to previous case (Fig. 3), but with daily commercial demand at $685 \mathrm{kWh}$ (Fig. 4), in addition to power from the grid, profitable is a PV installation.

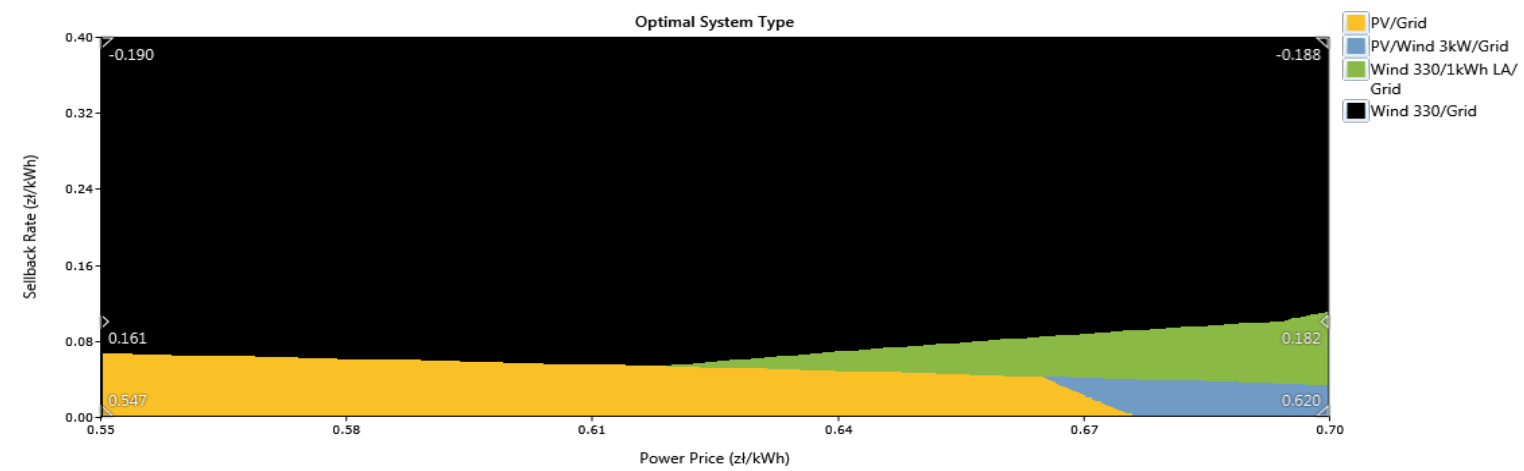

Fig. 5 Sensitivity analysis for Power and Sellback prices. Average Wind speed 4,79 m/s; Residential load 5,95 kWh/day; Commercial load $685 \mathrm{kWh} /$ day 
In the next case (Fig. 5), we see the variation in the optimal types of configured installations in the variant with an increased average wind speed to $4.79 \mathrm{~m} / \mathrm{s}$. We also see that in this case the Lead-Acid battery supporting the wind turbine is used.

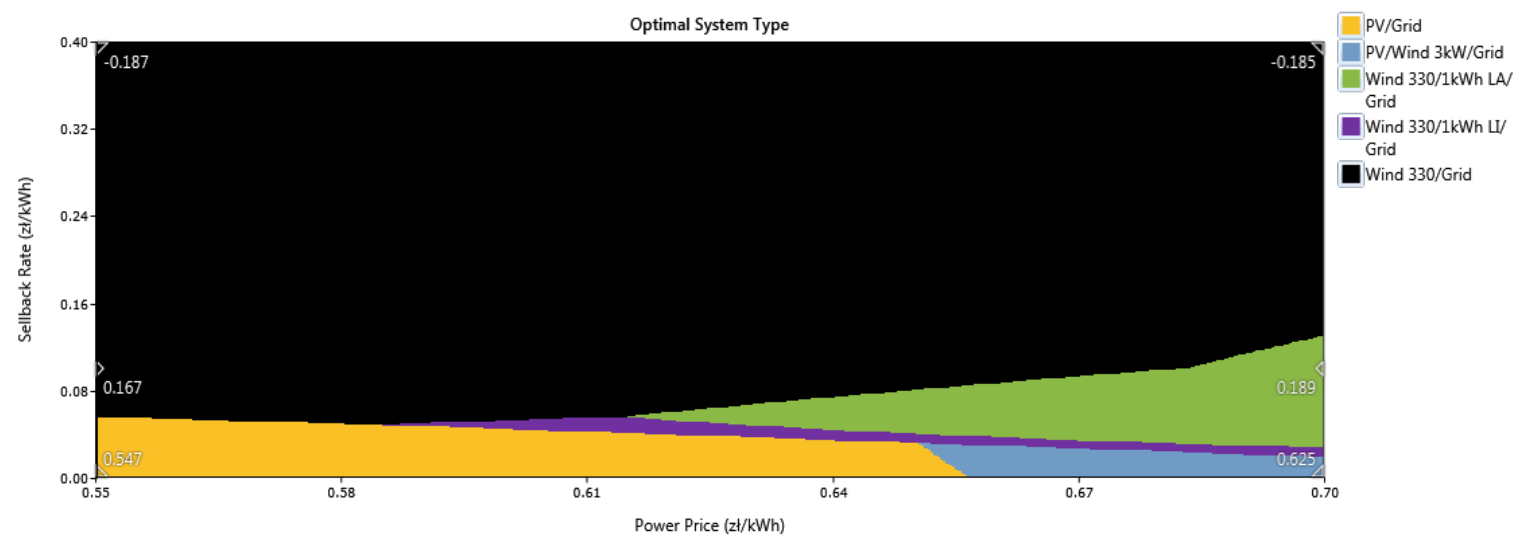

Fig. 6 Sensitivity analysis for Power and Sellback prices. Average Wind speed 4,79 m/s; Residential load 59,5 kWh/day; Commercial load 685 kWh/day

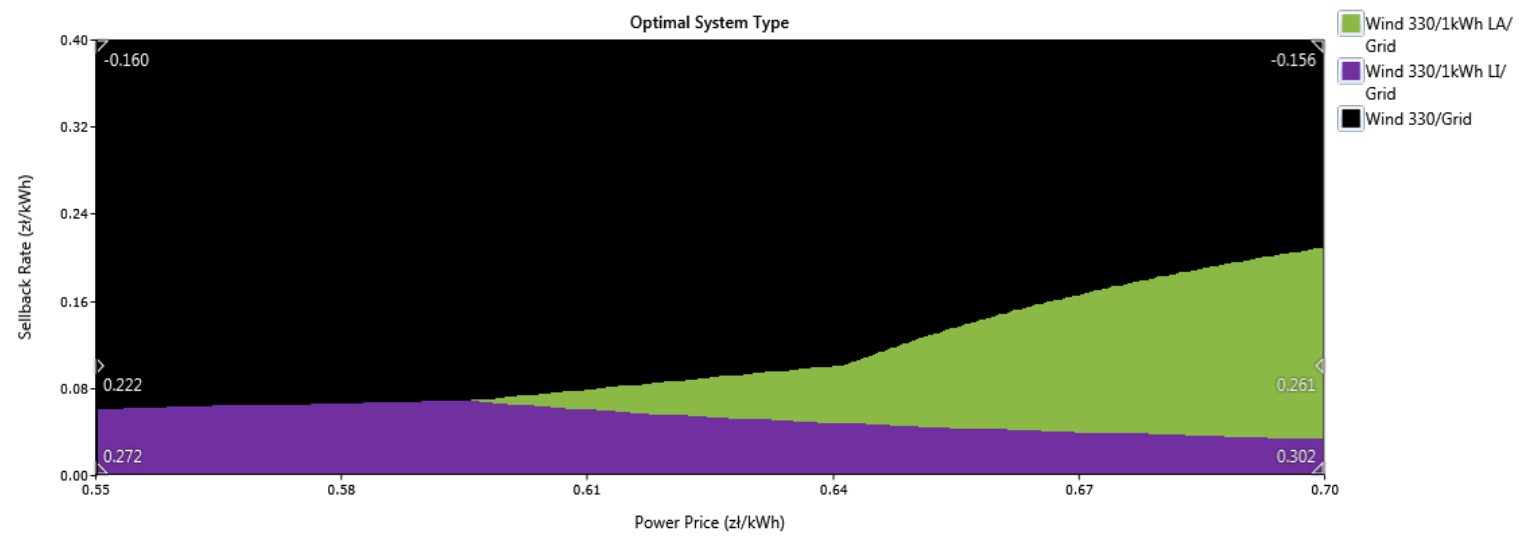

Fig. 7 Sensitivity analysis for Power and Sellback prices. Average Wind speed 4,79 m/s; Residential load 595 kWh/day; Commercial load 685 kWh/day

The increase in energy consumption by residential customers in the next option (Fig. 7) leads that the PV installation is not recommended (at given costs). Higher consumption of electricity by residential customers, to the level similar to commercial load, resulted in profitability of Lead-Acid batteries and more expensive Lithium-Ion batteries.

Analyzing the sensitivity of the average daily consumption of electricity by commercial and individual customers (Fig. 8 and Fig. 9), we see the changing role of PV installations, which with larger demand are displaced by wind turbines (for average wind speed $4.79 \mathrm{~m} / \mathrm{s}$ ). At a higher price of electricity (0.70 PLN / kWh), a $3 \mathrm{~kW}$ wind turbine starts to compete with PV (Fig. 9). 


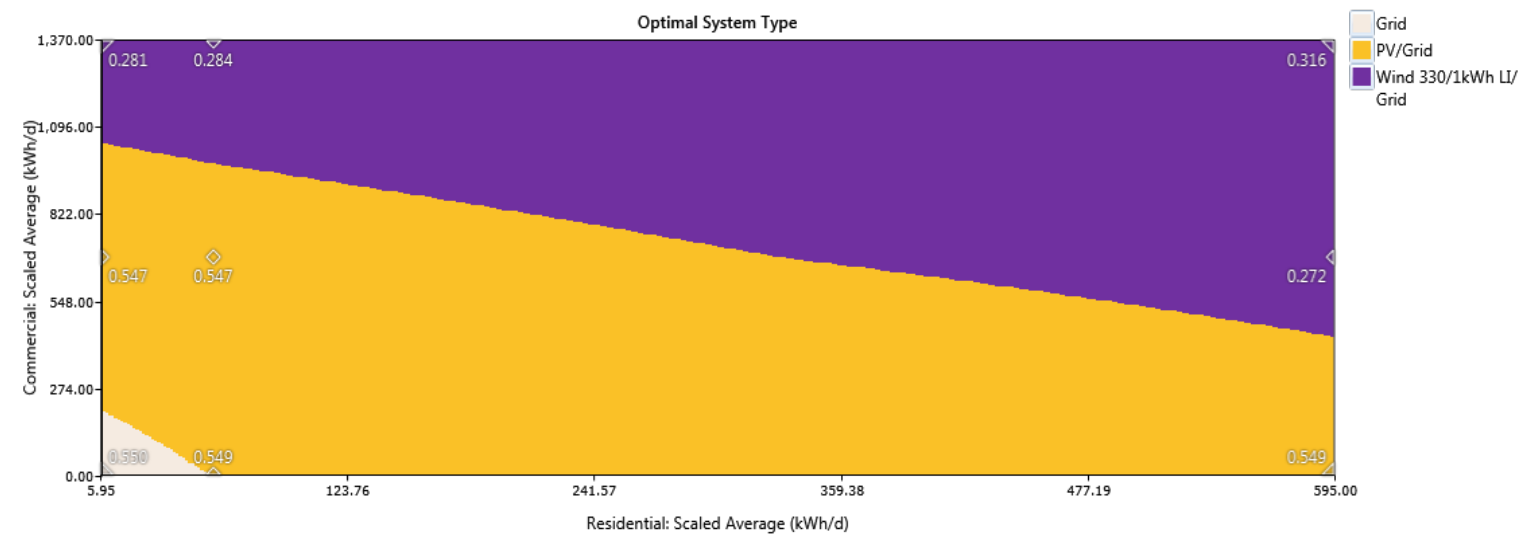

Fig. 8 Sensitivity analysis for electricity loads - Commercial and Residential. Average Wind speed 4,79 m/s; Power price 0,55 PLN/kWh, Sellback price 0 PLN/kWh

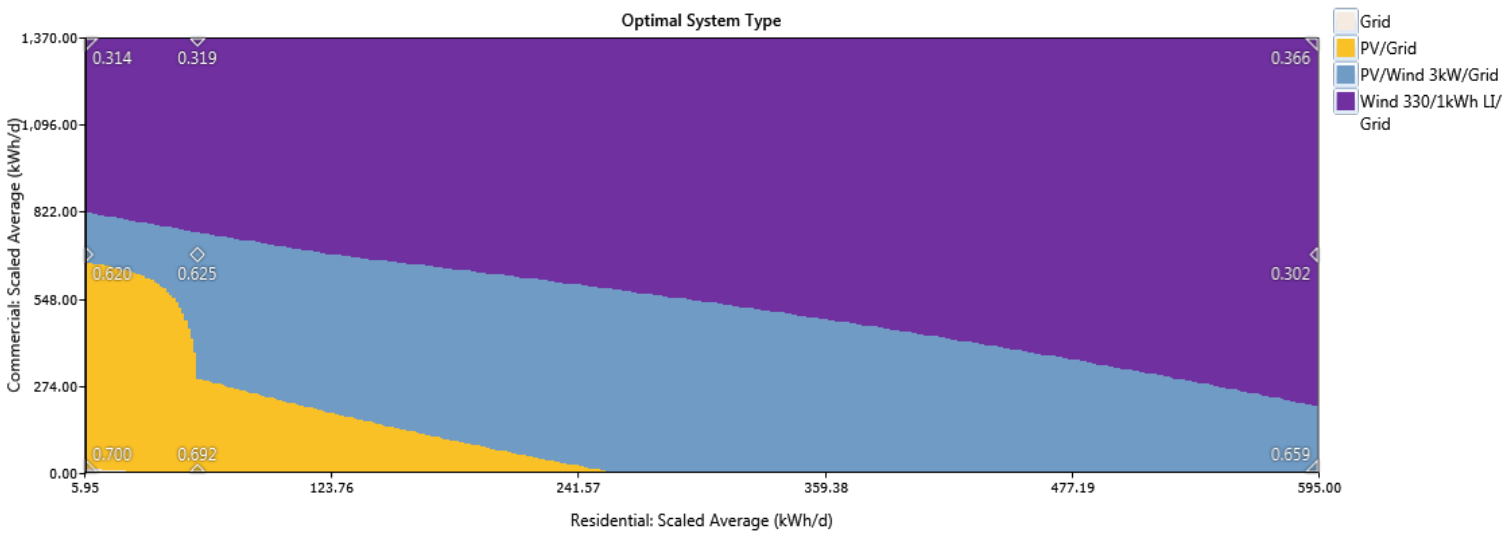

Fig. 9 Sensitivity analysis for electricity loads - Commercial and Residential. Average Wind speed 4,79 m/s; Power price 0,70 PLN/kWh, Sellback price $0 \mathrm{PLN} / \mathrm{kWh}$

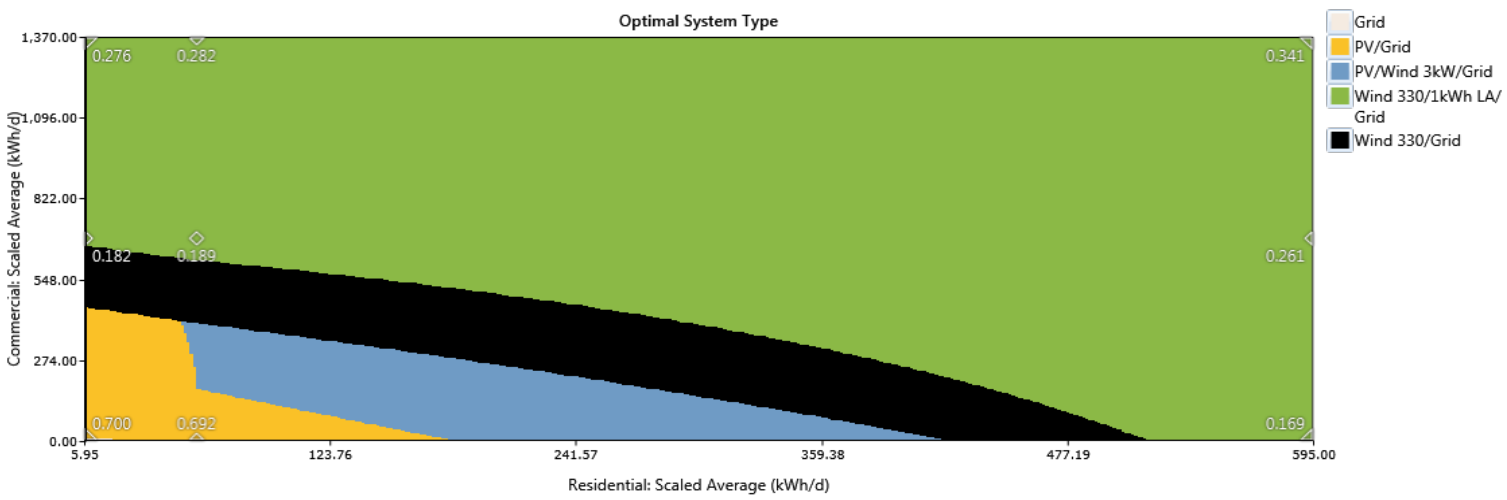

Fig. 10 Sensitivity analysis for electricity loads - Commercial and Residential. Average Wind speed 4,79 m/s; Power price 0,7 PLN/kWh, Sellback price 0,1 PLN/kWh 
Introducing the possibility of selling electricity to the grid causes that the energy price of customers is significantly reduced (Fig. 10), and in the case of increasing the sales price to the level of 0.70 PLN / kWh recommended installation configurations in the cluster model bring income, the price of electricity is negative (Fig. 11 and Tab. 5).

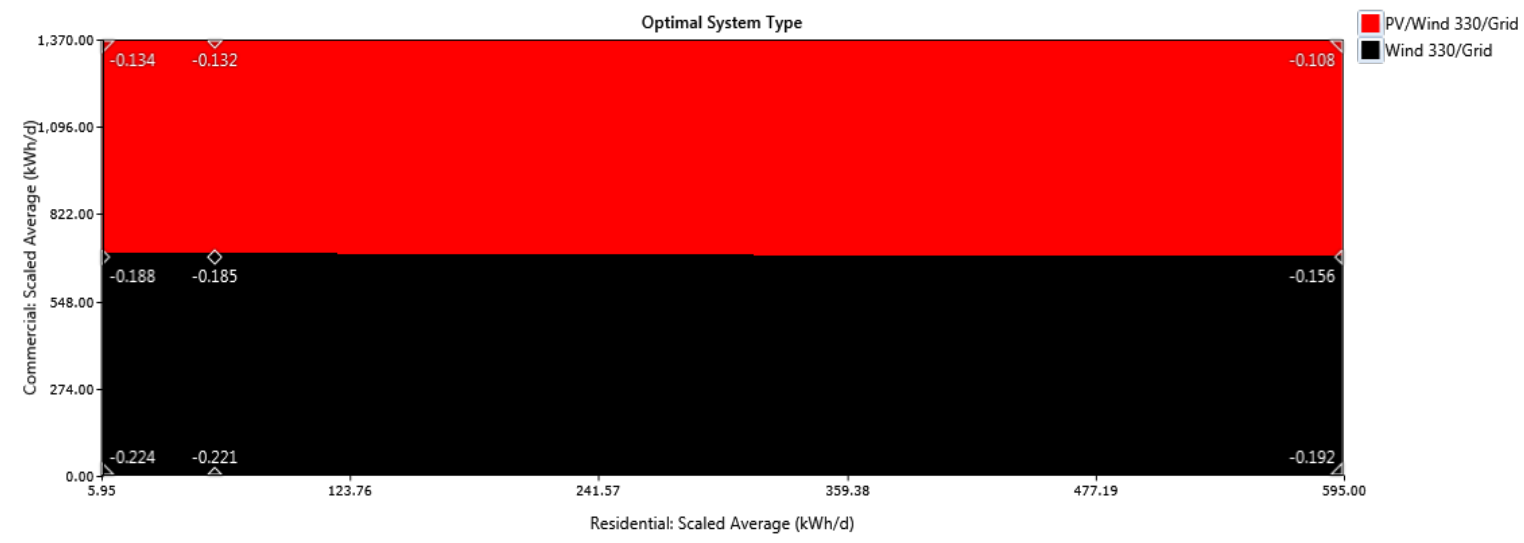

Fig. 11 Sensitivity analysis for electricity loads - Commercial and Residential. Average Wind speed 4,79 m/s; Power price 0,7 PLN/kWh, Sellback price 0,4 PLN/kWh

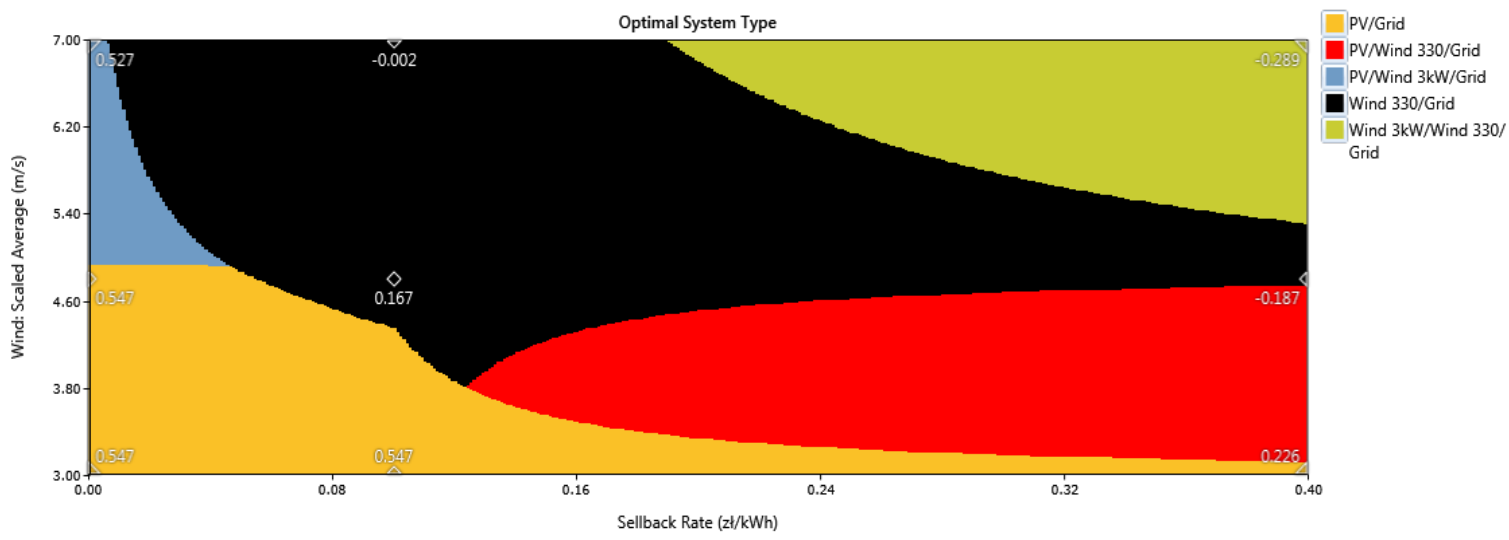

Fig. 12 Sensitivity analysis for average Wind speed and Sellback price. Average Residential and Commercial loads 5,95 kWh/day and $685 \mathrm{kWh} /$ day respectively; Power price $0,7 \mathrm{PLN} / \mathrm{kWh}$

Fig. 12 and Fig. 13 show optimized installations depending on the sellback electricity price and the average wind speed. The dependencies presented in both drawings illustrate the economic efficiency (the cost of energy significantly reduced or the cluster brings profits) and the technical complexity of the solutions. 


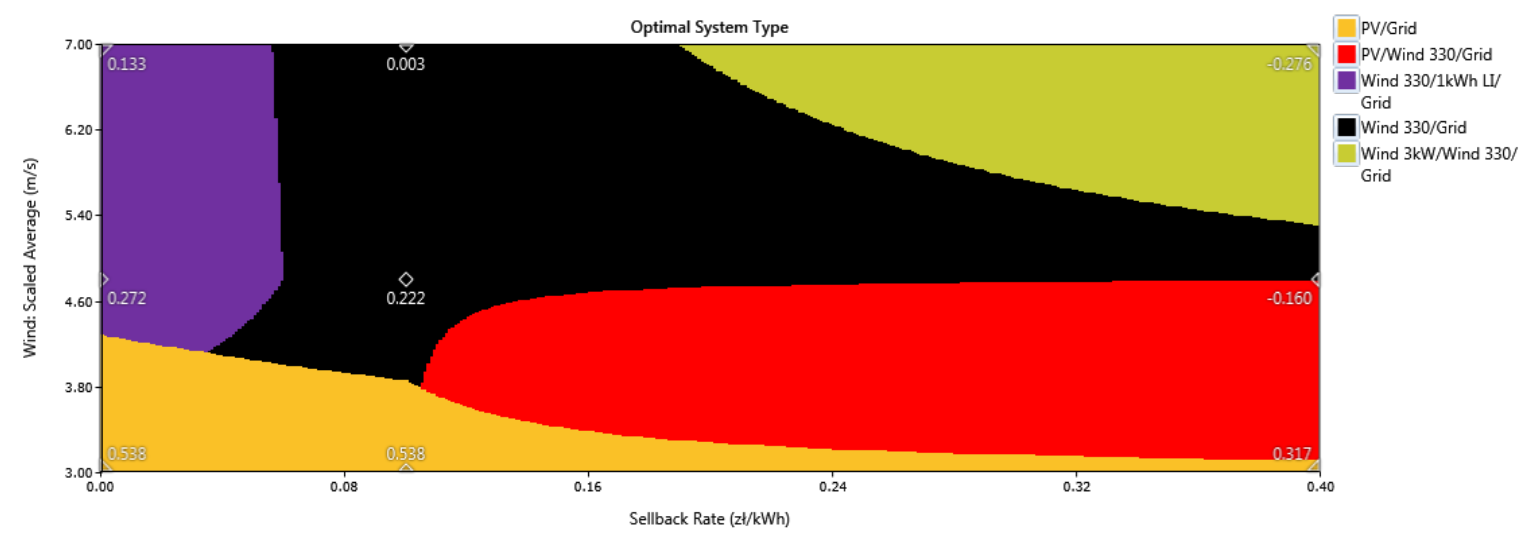

Fig. 13 Sensitivity analysis for average Wind speed and Sellback price. Average Residential and Commercial loads $595 \mathrm{kWh} /$ day and $685 \mathrm{kWh} /$ day respectively; Power price $0,7 \mathrm{PLN} / \mathrm{kWh}$

The presented method of analysis of energy cluster by the software for microgrid and distributed generation power system design and optimization includes several simplifications that should be taken into account when interpreting the results and formulating conclusions:

- Customers having within the cluster strongly differentiated energy demand (e.g. in terms of daily and seasonal variability resulted from their nature) have been aggregated into two categories, individual and commercial customers, which is a far-reaching simplification.

- The uniform electricity tariff applied for residential and commercial consumers (in practice, these rates are differentiated), without taking into account other components of tariffs, i.e. fixed, variable, network fees, etc.

- The rules of the sale of electricity to the network have been simplified to the simple sellback price, in practice, the principles of settlements are more complicated.

All taken simplifications are justified by the reason that they were used for identification and illustration of general interdependencies. Some of them can be minimized by using the advanced settings available in the program.

\section{SUMMARY}

The purpose of the article was to conduct a quantitative analysis of the efficiency of electricity supply balancing in the model of an energy cluster.

The presented method allows a detailed analysis of balancing demand and supply with the given accuracy (in the example, hourly balancing in a year perspective was considered). The use of a simulation program that enables the performance of sensitivity analyzes allows for a variant assessment of decision situations.

The results of the calculation example show that the use of renewable energy sources is beneficial in the given configuration of electricity demand. The analysis indicates, however, that the premises may be strictly economic.

The application of Lead-Acid and Lithium-Ion batteries, besides economical reasons, is influenced by all analyzed factors (wind speed, the intensity of demand and load profiles, prices as well), which 
make it economically and technically justified to install systems combining several types of sources optimized according to such criteria.

The proposed method, along with the presented tool, according to the author, gives not only the possibility of performing complex analysis, but also performing them in a more accurate way with detailed and up-to date data. These analyzes may indicate the strengths and weaknesses of the cluster and show economic results of changing parameters.

\section{Acknowledgement}

The article is the result of research for a project financed by the National Center for Research and Development entitled Highly specialized platform supporting civil emergency planning and rescue in the Polish public administration and organizational units of the National Firefighting and Rescue System, agreement DOB - BIO7/11/02/2015 realized by the consortium: Warsaw University of Technology (Faculty of Management), Medcore sp. z o.o.

\section{BIBLIOGRAPHY}

[1] Dz.U. 2015 poz. 478, z późn. zm., 2015, “Ustawa z Dnia 20 Lutego 2015 r. o Odnawialnych Źródłach Energii."

[2] KAPE, WISE, and Atmoterm, 2017, Koncepcja Funkcjonowania Klastrów Energii w Polsce, Warszawa.

[3] Masłowski, P., 2011, "Basic Assessments for Energy Storing in Long Endurance Solar Powered Aircraft," Transactions of the Institute of Aviation, (217), pp. 107-115.

[4] Leutenegger, S., Jabas, M., and Siegwart, R., 2011, "Solar Airplane Conceptual Design and Performance Estimation,” Journal of Intelligent \& Robotic Systems, 61(1), pp. 545-561.

[5] Rice, D., 2016, "Solar Impulse 2 Takes off from S.F.(NEWS)(Brief Article)," USA Today, p. $04 A$.

[6] IRENA, 2017, ELECTRICITY STORAGE AND RENEWABLES: COSTS AND MARKETS TO 2030, International Renewable Energy Agency.

[7] EPRI, 2002, Handbook of Energy Storage for Transmission or Distribution Applications, 1007189, Electric Power Research Institute, Palo Alto, CA.

[8] Bossart, S., 2014, “Topical Report on DOE Smart Grid ARRA Microgrid Projects.”

[9] Mataczyńska, E., 2017, Klastry Energii - Korzyści i Szanse Realizacji, 2/2017, Instytut Polityki Energetycznej.

[10] Montuori, L., Alcázar-Ortega, M., Álvarez-Bel, C., and Domijan, A., 2014, "Integration of Renewable Energy in Microgrids Coordinated with Demand Response Resources: Economic Evaluation of a Biomass Gasification Plant by Homer Simulator," Applied Energy, 132(C), pp. 15-22.

[11] Waqar, A., Wang, S., Shi, X., Zheng, X., Salih, H., and Khalid, M., 2015, "Generation Expansion Planning and Evaluation in the Context of Microgrids Using HOMER,” Advanced Materials Research, 1092-1093, pp. 424-428.

[12] Kunikowski, G., 2016, "Instalacje prosumenckie z perspektywy rachunku ekonomicznego," Energetyka prosumencka próba konsolidacji w aspektach: przyrodniczym, społecznym, ekonomicznym i technicznym, J. Popczyk, R. Kucęba, K. Dębowski, and W. Jędrzejczyk, eds., Wydawnictwo Politechniki Śląskiej, pp. 134-145.

[13] GUS, 2017, Energy Consumption in Households in 2015, Central Statistical Office, Warsaw. 


\section{MAGAZYNOWANIE ENERGII ELEKTRYCZNEJ W KLASTRACH}

\section{Streszczenie}

Celem artykułu jest przedstawienie wyników analizy i oceny wykorzystania klastrów energetycznych jako magazynu energii elektrycznej. Wykorzystując oprogramowanie do optymalizacji mikrosieci opracowano i poddano analizie przykładowy model mikrosieci współpracującej z siecią elektroenergetyczną. W modelu wykorzystano profile zużycia energii odbiorców przemysłowych i indywidualnych, instalacji fotowoltaicznych i wiatrowych oraz akumulatorów energii elektrycznej.

Słowa kluczowe: klastry energetyczne, magazynowanie energii, mikrosieci 